Archives of Agriculture and Environmental Science

\title{
Agro-tourism: Prospects, importance, destinations and challenges in Nepal
}

\author{
Saugat Khanal* (D) and Mamata Shrestha \\ Faculty of Agriculture, Agriculture and Forestry University, Bharatpur 44200, Chitwan, NEPAL \\ "Corresponding author's E-mail: ksaugat506@gmail.com
}

\section{ARTICLE HISTORY}

Received: 18 October 2019

Revised received: 01 December 2019

Accepted: 03 December 2019

\section{Keywords}

Elements of Agro-tourism

Homestays

SWOT analysis

Tourist destinations

\section{ABSTRACT}

Nepal, being an agrarian country and having diverse geography, has tremendous potential for both agricultural and tourism development. In addition, the synergistic effect on national income would have resulted if both agriculture and tourism is practiced in an integrated approach. Keeping this point in view, a study was undertaken to realize agro-biological aspects of Tourism, prospects, importance, destinations, challenges, and suggestion for the improvement in the present chaos of agro-tourism in Nepal. Pieces of Literature were collected from different Journal articles, Government institutes and other relevant reports were studied and the major findings were summarized. Nepal has innumerous tourists destination hubs like majestic and ancient Hindu architect of Kathmandu valley, the serene and tranquil natural beauty of Pokhara, high mountainous emblazoned with snow and diverse flora and fauna; in addition, Ghandruk, Illam, National parks and conservation areas across various ecological zone, Mustang, Dolakha, Solukhumbu, traditional communities, and so on add natural beauty. Agro-tourism in Nepal is in its very beginning and there are many weaknesses, challenges, and threats that retard the successfulness of Agro-tourism which need to be solved soon as "Nepal Tourism vision-2020" is near to mouth. The contribution of the tourism part on Gross Domestic Product has remained mediocre despite regardless of prodigious potentiality. In later days, the homestay and agro-tourism activities have started in different parts of the country in pursuit of noteworthy progress in the tourism sector. After analyzing the relevance of Agro-tourism in Nepal, the possible promotional strategies have been suggested.

(C)2019 Agriculture and Environmental Science Academy

Citation of this article: Khanal, S. and Shrestha, M. (2019). Agro-tourism: Prospects, importance, destinations and challenges in Nepal. Archives of Agriculture and Environmental Science, 4(4): 464-471, https://dx.doi.org/10.26832/24566632.2019.0404013

\section{INTRODUCTION}

Nepal, small landlocked, autonomous, mountainous country; is located between Tibet (China) to its North, and India to its East, West, and South. Stretching approximately $193 \mathrm{~km}$ North-South and $885 \mathrm{~km}$ East-West and $1127 \mathrm{~km}$ far from the approach of the sea, Nepal spreads to an area of $1,47,181$ sq.km(56,827 sq. miles) at a latitude between $80^{\circ} 4^{\prime} \mathrm{N}$ latitude, $88^{\circ} 12^{\prime} \mathrm{E}$ longitude. Its altitude varies from 70 meters in the Terai to the highest point in Earth, the summit of Mt. Everest at 8848 meters, all inside a distance of about $160 \mathrm{~km}$, resulting in climatic conditions varying from sub-tropical to arctic. Agro-tourism, is, literally defined as the Tourism activities exercised by farmers through the utilization of their own farm in consonance with the rationale of "connection," "complementarity" and "nonprevalence (Sonnino, 2004). It is the amalgamation of tourism and agriculture. Agro-tourism is constantly hybridizing and evolving which promotes excitement, discovery, and anticipation (Ogidi and Odiba, 2014). Agro-tourism is defined as any custom developed on a working farm with the objective of attracting tourists (Barbieri and Mshenga, 2008). It is one of the most extensive and influential forms of tourism in Austria (Sharpley and Vass, 2006), Germany (Oppermann, 1995), Norway (Haugen and Vik, 2008), Greece, Poland, and China (Upadhyaya, 2006) and other parts of Europe and America. The main objective of the study is to figure out the possible achievable benefits from the agro-tourism as well as the strategies to promote the agro-tourism sector. Due to the generation of low 
revenue from farming activities, it has led farmers to diversify from the agricultural base (Fleischer and Pizam, 1997; and Rickard, 1983). The journey towards a sustainable development paradigm arises from the local actors, especially the farmers, who are looking for "new ways" of doing business, analyzing the viability of alternative economic schemes (McGehee and Kyungmi, 2004). However, the standard of tourism inclusive with agro-tourism is moving forward in an inclining graph. Encouraged and motivated by the 2018 tourist arrivals, Tourism in Nepal commenced its 2019 journey on a positive note (Figure 1). Right from the very first month of the year 2019, the country has already started acquiring the interesting no. of Tourists from all around the world. Tourist's arrival increased by $8 \%$ to 975,557 visitors between January-October, 2019, compared to the same duration of time last year (Sansar, 2019). The maximum number of tourists arrived from India 169,952 followed by China (134281), US (77798), Sri-Lanka (57240), and UK (50393)

(Sansar, 2019). However, lots of barriers and challenges are seen in agro-tourism development through the study report for which the possible promotional strategies are to be discussed and implemented strictly.

\section{Relevance of agro-tourism in context of Nepal}

Nepal is a developing agrarian country, having high than $66 \%$ of people directly engaged in farming, employing two-thirds of the country's labor force and contributing nearly $28 \%$ of the Total Gross Domestic. One-third of the Gross Domestic Product is contributed by agriculture and due to diversified agro-climate prevailed in the country there are plentiful opportunities in Agriculture (Paudel, 2016). Agriculture is the main element of the Nepal economy. The sustainable use of the potentials of tourism handicrafts, high value low-volume agricultural products, nontimber forests, and human products determines the socio-economic development of Nepal ( MA and Pandey, 2011). Nepal is richly endowed with agro-biodiversity. Agro-tourism in Nepal emphasized on local foods, small rural businesses, Homestays, handicrafts, and low impact transportation (Park and Yoon, 2011). Nepal boasts immaculate natural beauty, skyhigh Himalayas Range and boundless culture and traditions spread out all over the country. In Nepal, the agriculture sector encompasses forestry, fishery, hunting, and farming and, the Nepali industrial activity also chiefly the processing of agricultural products, including pulses, jute, sugarcane, tobacco, and grain. Looking at it the other way, Tourism is the largest industry in Nepal and is the largest source of foreign exchange and revenue (Figure 2). As reported by lonely planet, Kathmandu has made entry as the $5^{\text {th }}$ top travel destination while tripadvisor.com has ranked Kathmandu at $19^{\text {th }}$ out of 25 best tourist destinations in the world for the year 2019. These facts affirm that there are many places like Kathmandu that could fascinate tourists from all around the world. The year 2020 is declared to be celebrated as "Tourism Year for Nepal". Therefore, the development of agriculture and Tourism is a key factor for the national economy and, agriculture is the backbone of the country's rural and national economy. That is why agro-tourism is one of the most attractive and fashionable ways of doing Tourism in Nepal. In this context, a study was embarked/ undertaken to figure out the status, prospects, challenges, and destination of agrotourism, solely for creating awareness among tourists all around the globe. Agro-tourism can take three forms: can be developed as alternate industry to agriculture which has failed to evolve despite constant focus or can be developed to preserve the viability and durability of rural localities, and can be developed as an activity to rejuvenate non-profitable agricultural activity.

\section{Why agro-tourism?}

Country farmers are working hard to meet their demands and fulfill their desires. Even if they work hard they are not pleased with their income. They can almost not meet their household expenses and other expenses. They cannot afford a good quality of life for them and their families. Because of the low income from their occupation, they have a poor financial condition. Every year, due to poverty, the suicide rate of farmers is tremendously increasing in South-Asian countries including Nepal. Thus, Agricultural development in Nepal is crucial to provide daily needs to those hard-working farmers, slow down imports, increase trading, solve the unemployment and provide raw materials to industries that can be mutually and thoroughly achieved with Tourism as Agro-tourism. It can be used to persuade and inspire farming communities to raise their crops in an eco-friendly demeanor and to conserve the biodiversity of farms (Dangol and Ranabhat, 2007). It allows tourists to come in close contact with the dwellers of small, rural villages and to be engaged in traditional ways of agriculture still prevailing in this age. Tourists can get a chance to know about different indigenous agricultural practices, such as how crops are harvested, marked and conserved, how vegetables can be raised organically, how freshly picked fruits are converted into delicious marmalade, and so on (Pandey and Pandey, 2011). Nepal is endowed with the agro-biodiversity and embellished with the geographical tranquil sight and landscape. Being an agriculture country, there is an unlimited scope of the agro-tourism. With the development in the realm of the technological sector and city orientation settlement of the people, many children as well people are not well familiar with the agricultural practices and management. Still, many people from the world are not known about the plantation of rice. The technique of plantation varies with the region to region. The hard-working farmer converts the field into an opera house theater where they sing the local songs (asare geet) and exchange their days going on for avoiding the sense of hardworking. Exchanging of the feeling of life and the mutual understanding in the course of working along with other time could be the way for fascinating the tourists easily. Rice, maize, and wheat are the main crops in Nepal. Terai is regarded as the storehouse of Nepal which has the eye-catching potential for the tourists. Buckwheat, millet, barley are the major crops in the high hills. Citrus along with the important cash crops like ginger, coffee, cardamom, tea, etc. The practice of on season and off-season vegetables is all over the nation which could be the milestone for the improvement of agro-tourism. Similarly, many 
pocket areas are flourished throughout the nation like a mushroom for Chitwan, off-season vegetables for Dhading, tea for Illam, etc. are the benchmark for the scope of expansion of agro-tourism through which tourists can get the field trial and production which furnishes their boundary of knowledge. AgroTourism is an intricate network, an opportunity maybe today to this contemporary society to assure both farmer's assets and national Gross Domestic Product. It provides additional income source and employment opportunities to the traditional farmer which is a better alternative way than migrating to the Gulf countries in search of employment. The fashion of welcoming to tourists, the hospitality of villagers, sharing and helping custom, working with tourists are the basic features of a rural society which develop keenness for visiting Nepal repeatedly and this helps for the flourishing of agro-tourism. Homestay in the village can be run satisfactorily in which the whole member of the society accommodate to entertain the tourist. It provides appropriate paths to protect natural habitats, natural resources, special places, and naturally beautiful scenic areas (Singh and Mishra, 2016). One of the prime rationales of agro-tourism is to create the opportunity to contribute to one's community, develop the hospitality tradition of the people, build-up morals and cultural discipline and combine agriculture with recreation (Getz and Carlsen, 2000; Maude and van Rest, 1985; Putzel, 1984; Weaver and Fennell, 1997).

\section{Destinations of agro-tourism}

National parks and conservation areas as a prime destination of agro- ecotourism in Nepal

Within the small area of the country territory, Government of Nepal has established 12 National Parks, 20 protected areas, 3 Wildlife reserves, 6 Conservation areas, 1 hunting reserve, and 9 Ramsar sites. Sagarmatha National Park and Chitwan National Park (oldest of Nepal) were enlisted in the world heritage site by UNESCO in 1979 A.D. and 1984 A.D. respectively. Chitwan National Park is recognized as the best conservation area in all of Asia with a fascinating range of wildlife roaming free in its jungles and grasslands. Sagarmatha National Park, is situated at high altitude, possesses much alpine agricultural vegetation; Cordyceps sinensis is the most important one of the types. Chitwan National Park, Bardiya National Park, Parsa Wildlife Reserve, and Shuklaphanta National Park are home to incredible varieties of flowering plants, wildflower varieties, shrubs, alluring vegetation, great-looking trees, and additionally vines, air plants and creepers and so on. These protected areas are very crucial for conservation efforts in Nepal, as 80 of the 118 ecosystems identified in Nepal are included within them. These areas cover a wide range of forest zone inside where different types of trees grow. Every year, millions of tourists visit these areas just to enjoy the nature of such agro-biodiversity. The area is also high potential for producing crops and vegetables. The elementary direct target beneficiaries are the poor farmers, unemployed youths and women mainly engaged in small scale agriculture activities. Moreover, it brings tourists more close to nature and rural activities in which they can participate, be entertained and feel pleasure via exploration.

\section{High altitudinal destinations}

The myriad of Floras found in Nepal offers to explore our national flower Rhododendron arboreum that has 32 species at about $1200 \mathrm{~m}$ to $3500 \mathrm{~m}$ altitude. It has a white, pink, red, and mixed color. There are altogether 319 species of the orchid flowers. Caterpillar fungus is called Yarsha gumba in the Nepali language that is found above $\mathbf{4 0 0 0}$ meters. Stellaria decumbent is the very important flower found only in Nepal which grows at the highest altitude in the world. There are unique species of mushroom named Traphina nepalensis which is found only in Nepal. Livestock farming also enhances Agro-tourism. Over 6500 species of flowering plants, 1500 fungi species, over 350 lichen species are found in Nepal. Particularly, in the Himalayan region there are different animals like Yak, Donkey, Mule, Sheep, chauries (yak-cattle crosses), Himalayan goat, Horse, etc. through which the tourists who are not familiar with such animals or those who have not ever seen them get the opportunity to collect the lifetime experience and knowledge about animals. Jumli Marsi Rice is one of the healthiest and tastiest rice of Nepal that is farmed at chill fresh weather and highest altitude of the world which can foster agro-tourism in rural hilly areas.

\section{Traditional agro-tourism community}

No doubt to say, Nepal's agricultural product is one of the best qualities in the world. Many tourists intended food brands are made accessible concerning the interest of tourists. Rural economies have been profoundly changed with time due to universal restructuring, change in consumer needs, including free trade and enhanced production (Mascarenhas, 2001). Considerable productions of traditional products are produced within the community by locally accepted technology. These include Chhurpi or Durkha production from traditional cheese of domestic yak and cattle in the Himalayan region. Dheedo with Gundrook is one of the most splendid and noteworthy Nepali identity foods for tourists. Vegetable form of Spinach, Aaloo Tama is legitimately alluring the tourists towards the rural community. Most importantly, Nepalese wine like Dadaghare, Hinwa, Grapple, Divine and many others are globally renowned that are prepared from the agricultural products like Rice barn, Wheat, Millet. Chauri's milk and meat are also equally amiable and favored. The community offers special Nepali food "daal bhat tarkari" with local ingredients. A rural community is attributed by diversified autonomous entities (organization and people) that dwell in rural community i.e. of cultural, physical, social and technical backwardness and through agro-tourism, these areas can be developed properly (Ilbery et al., 2004).

\section{Agricultural fair and exhibition}

Different agro-organizations have been organizing a lot of promotional activities such as training, workshop publication, 
trade and exhibitions, among these activities The Floriculture trade fair is the most important one. Agro-trade fairs are recognized all over the world as one of the most effective tools of marketing for floriculture, olericulture and pomiculture business. The expo manifests the contemporary developments in farming sectors of the Nepalese economy. While on the consumer sector it serves to instigate new brands and put on display a wide collection of agro-products, its business section attracts a large number of visitors from all Nepal and abroad. Animals are also kept there along with their products. Some eye-catching and heart-touching traditional rural agro-architect may be of something very new scene for tourists that encourage them to buy these products, learning the way to make them, and their traditional importance. Exhibition directly benefits the farmers, exhibitors, and the visitors as well as tourists and ultimately the entire nation through economy elevation. The agro-exhibition is a remarkable terrace for interaction, power of live communication and marketing to showcase vision, exchange and trade for all the stakeholders, and demonstrate products. International Fair of Economy, Agriculture, Food and Tourism performed Nepal poultry expo, Fair of Apple, Fair of wine, Fair of livestock animals, seeds, agro-machineries, exportable decorative flowers, Tea, Cardamom, medicinal plants and so on.

\section{Others}

Traditional Plantations, Green healthy gardens, Farm museums, Rural village rum shops, Herb/Exotic plots, created and Craft

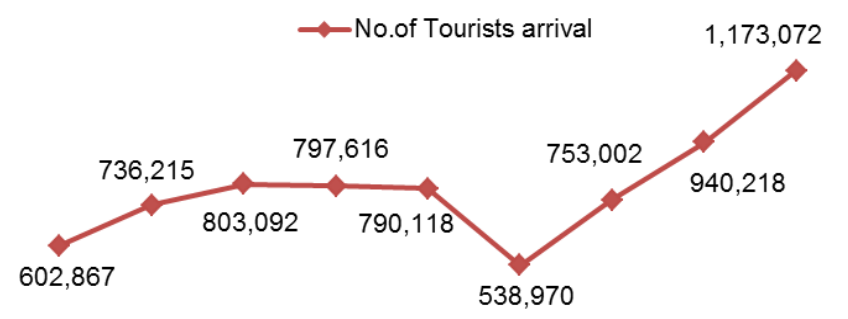

$\begin{array}{ccccccccc}2010 & 2011 & 2012 & 2013 & 2014 & 2015 & 2016 & 2017 & 2018 \\ & \text { Years }\end{array}$

Figure 1. Trend of tourist arrival in Nepal (Source: Nepal Tourism Board, 2019).

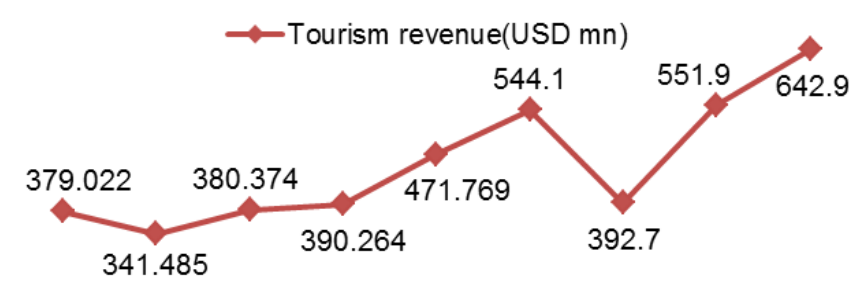

$\begin{array}{lllllllll}2010 & 2011 & 2012 & 2013 & 2014 & 2015 & 2016 & 2017 & 2018\end{array}$ Years

Figure 2. Revenue from tourism in Nepal (Source: Nepal Tourism Board, 2019).
Markets, Agricultural fairs, indigenous festivals, Memorable events, Agricultural tours, Village bed and breakfast, Spas, Alternative medicines, Farm-processing, Farm-trade with Tourism Operators are the most notable agro site and destination for international tourists (Waithe, 2006).

\section{Elements of Agro-tourism development}

Primary criteria for defining agro-tourism destination are local attraction, homogeneity or heterogeneity, the cardinal of visitors and the status of development of tourist destinations. In the field of Hospitality and Tourism Research, many studies have been performed to analyze the level of tourist satisfaction. For e.g. Bowen and Clarke, 2002: Ryan and Cessford, 2003; and Yuksel and Yuksel, 2001a,b have done research on tourist satisfaction. Tourism is realized in a particular environment so the environment and its quality can favor or disadvantage tourism activities. Elementary variables and component of the attractiveness of any destination and the main elements of the tourist product and its further development as an agritourist destination are: elements of accommodation; attractiveness of tourist destination; environmental elements; socio-cultural; elements of the offer; infrastructure facilities; political stability; the local involvement in tourism; elements of promotion; marketing; information system. It has three elements: Accommodation, Food, and Entertainment (Table 1).

Importance of agro-tourism for rural settlements in Nepal Agro-tourism is one of the most crucial parameters to improve the nation's economy of a country like Nepal where major occupation is Farming and having lots of potential tourist destination hubs. Rural areas where agro-tourism will be exercised will become the places where all elements of local sustainable development will be collected. Agro-tourism authorizes new businesses and jobs on the local level. It can also act on the policymaking system of the locality; forcing it indirectly to find sources of financing for achieving objectives. It also expands the farmer's income. Civilization, education and cultural factors get promotion positively. It depicts the identity of popular rural localities. Agro-tourism can be a good way of diversifying rural economies in rural areas and can provide alternative incomes for the farmers of those areas. There will appear the concern in remodeling the infrastructure, of creating a spiritual life of rural localities, strategic objectives may be achieved regarding the human factor; technical endowments, and heritage conservation. It also establishes social and economic connections between urban and rural inhabitants. It changed the thoughts of the people and increases the reputability of agricultural activity from the urban peoples' perspective. It works to enhance the ability to bring the main primary industry (agriculture) and the major service sector (tourism) together, by creating a win-win situation for both parts. Tourism is a tool of economic development that improves investment opportunities, tax revenues, cultural and natural attractions, accommodation services and outdoor recreation opportunities (Andereck et al., 2005; Kiriakidou and Gore, 2005; Kandampully, 2000). 
Balancing must be established between three pillars of Agro-tourism development: Agro-economic, Environmental, and Socio-cultural aspects in order to achieve long-term sustainability (Latip et al., 2015). Tourism contributes to national profitability, employment generation, and economic diversification (Ismail and Turner, 2008). Sustainable agro-tourism fosters the social and economic activities in rural area without altering social and artistic heritage and natural environment (Ammirato and Felicetti, 2014. Tourists can involve in various agro-tourism activities at the farm at the same time and will get a better opportunity to enjoy Nepal in a different way. Agro-tourism does the work of branding local agro-architectural products bringing progress in entrepreneurship in rural areas, generating employment opportunities capitalizing the youth for the development of the nation (Bhusal et al., 2018).

\section{Homestay agro-tourism}

So far, homestay tourism has been exercised in Nepal from prehistoric age, as tourists are respected as Atithi Devo Bhava (Guests are God), in the Nepali society. Due to innumerable ethnic community with a mosaic of cultures, ascribed to diverse social practices, has a huge possibility for the enthusiasts to enjoy homestay tourism in Nepal. Ghandruk is one of the most important places for homestay. Sirubari, Similarly, another homestay tourism destination is "Sirubari"(Syangja) for importing most of the consumable goods for tourists. Mustang has become one of the best homestay destinations of Nepal due to the availability of local homemade products and has been alluring many tourists since a few years. Others are Besi Sahar, Mustang, Illam, Pokhara, Chobhar hill, Parbat, Chitlang, Diktel, Namche bazar, Jiri, Kalinchowk and so on. The economic, environmental, and socio-cultural nature of farmer's community is affected by the tourism activities that are highlighted by the studies conducted by Ogorelc (2009), Vargas-Sánchez et al. (2009), Diedrich and Garcia-Buades (2009), Kayat, (2002), Andereck and Vogt (2000) and Long et al. (1990). Nepali villages are admirable; they are there for, to be exploited; nevertheless, we are not realizing the profit of our unrecognized, unexplored pristine villages of rural Nepal. Therefore, the Government of Nepal should begin promoting homestay tourism in Nepal. Every tourist enjoys the hospitality environment of the family such as dal, bhat, roti, fish, meat, milk, homemade yogurt and alcohol produced from millet.

SWOT (Strength, Weakness, Opportunities, Threat) analysis of agro-tourism in Nepal

The SWOT analysis helps to identify lists of important factors regarding agro-Tourism development. Towards the strength, many farmers have owned their own farm/land and other requirements of farming. These farms possess area specific crops, livestock species and tress contributing a unique agricultural landscape for the area. Beautiful natural landscapes consisted of forests, mountains, and grasslands that provide immense value for the environment. Farming activities are well performed by knowledgeable and experienced farmers in these areas. These young enthusiastic and diligent farmers can work hard throughout the year without any complication as there is no seasonal difference in the country. The availability of sufficient family labor at a significant level is also a positive plus point for agro-Tourism. Farmers practice both traditional farming activities together with modern farming techniques. Currently, there is a drift towards organic farming. Besides, these areas are prosperous in traditional (cultural) such as cane weaving, pottery making art, and craft industry.

There are still many weaknesses too. In spite of having basic knowledge about agriculture, the farmers have low awareness of the profit of agro-tourism and related aspects. To begin an agro-tourism, it needs at least three acres of land including primary agricultural activity with some livestock and accommodation facilities for 6-8 visitors but most of the farm in Nepal is small in size, Farmers have a weak level of leadership, entrepreneurship, and management and decision-making skills that are crucial in agribusiness activities. There lacks the concern for agro-tourism products and their quality standards. The standard of infrastructure facilities such as transportation, water, and power supply are not just enough for the determination of tourism destinations. It can lead to negative impacts on farmer's quality of life by changing the host's lifestyle (Tosun, 2002; Brunt and Courtney, 1999; McCool and Martin, 1994). The investment problem is also of a great deal and they have low accessibility of external resources required for the arrangement of facilities. Likewise, there is still a lack of relevant rural policies and regulations for the development of agro-tourism.

Table 1. Elements offered to tourist (Source: Ammirato and Felicetti, 2014).

\begin{tabular}{ll}
\hline S.N. & Elements offered to tourists \\
\hline 1. & Overnight accommodation \\
2. & Academic farm (e.g. milking cows, sheepdog display, cattle drives, feeding or petting animals) \\
3. & Dancing in agricultural occasion like planting of Rice. \\
4. & Active involvement in the life of the farm ('pick-your-own' facilities, participation in farm tasks) \\
5. & Tasting of self-made food \\
6. & Selling of self-made food \\
7. & Tasting of goods of other local farms \\
8. & Selling of goods of other local farms \\
9. & Horse riding \\
10. & Meal provision \\
\hline
\end{tabular}


There are some opportunities the farmers have with which agro -tourism can be flourished successfully. Numerous tourist destination places make easy to attract visitors. They are rich with agricultural, natural, cultural and religious attractions. Furthermore, bilateral co-operation among farmers and other organizations in these areas reveals the social capital that can be used for the development of the agro-tourism industry. Because of the presence of innumerable tourist destinations in these areas (ecotourism, culture tourism, adventure tourism, health tourism), mutual benefits can be obtained by having close relationships with them. Through horizontal linkages with other tourism -based activities, agro-tourism can generate new sources of income (Veeck et al., 2006). Since unemployment of the youth of these areas is high, these unemployed people can be employed. Both unemployment problem, as well as rural-urban migration can be somehow mitigated by agro-tourism. Also, many threats appear in the agro-tourism industry, the agricultural farm is all covered by the non-degradable wastes. So a need to apply appropriate waste management procedures for maintaining clean surroundings is essential. On this subject, the $3 R$ technique (Reduce, reuse and recycle) of waste and production of compost from the decaying waste are essential. Urbanization, Industrialization, and Modernization in the cultivable area are of great concern to be checked immediately.

Promotional strategies for the development of agro-tourism in Nepal

There is the proverb "where there is greenery there is peace and happiness". Concerning to this Nepal, being rich in the agrodiversity is a suitable nation for tourism development throughout the world. So, respecting the potential of agro-tourism in the sustainable promotion of ecology and the economy of the nation, there is immediate need of maintaining sustainable policy and long term vision along with the productive action which conclusively assists to raise our nation's name and fame in the world. In Nepal, Agro-tourism can be a new way to improve income by utilizing traditional knowledge, preserving biodiversity, maintaining a rural and agricultural way of life to motivate and encourage farming communities and enthusiastic youths to raise the crops in an eco-friendly manner (Maharjan and Dangol, 2018).

The rural tourism of Nepal is in its very beginning. However, there is not sufficient budget passed in the parliament in the name of agro-tourism development. Nepal depicts enormous untapped potential; potential centers of rural tourism are many villages, especially in the broad environment of major cities. The critical mass of resources and attractions can be achieved by a group of small scale operators for effective promotion to provide geographic identity and to target markets (Weaver et al., 1996). For every stakeholder, tourism is a socio-cultural event (Murphy, 1985). Tourism development can change the structure of the society in positive (Lankford, 1994) and negative too (Ap and Crompton, 1993). So, the impacts of tourism on society should be considered so that the benefits can be optimized (Brunt and Courtney, 1999). That is why the effective plans and policies for agro-tourism development are very important. Following are the strategies implemented and to be implemented:

\section{Strategies no. 1 (Nepal Tourism vision-2020}

The Ministry of Tourism and Civil Aviation in the conference with its industry partner has produced Nepal Tourism Vision2020 to guide tourism development throughout the nation. The vision complements the national effort of economic reform and integrates the soul of inclusiveness for a broad-based enabling environmental that sets the pace of gradual but focused change in the Tourism sector. The program will have ample space for agricultural market and agro-tourism.

Strategies no. 2 (Bettering livelihood and spreading benefits of tourism)

- Increased spending of Government in the Tourism sector to create infrastructures.

- $\quad$ Attract investment from private companies in generating tourism facilities. e.g, Hotel, Cable cars, Theme parks, etc.

- Identify and modify tourist places as tourism satellite sites around each hub.

- Conduct awareness campaigns that one may maintain and protect intellectual creations by deprecated groups and women.

\section{Strategies no. 3 (Expanded product offering)}

- Make better linkages of agro-tourism with other branches of the economy.

- Minimize the negative environmental impacts and maximize local ownership, community initiatives, employment opportunities, self-reliance, and economic benefits by applying sustainable development principles in Tourism.

\section{Strategies no. 4 (Destination marketing)}

- Established Tourism brand and other sub-brands of the country will be promoted as destination marketing.

- Internet marketing will be used to promote Nepal in the global source market.

- The capacity of Nepal Tourism Board will be strengthened as a National tourist organization.

\section{Strategies no. 5 (Aviation)}

- Tribhuvan International Airport (TIA), which has already reached a saturation point, is the only international airport in the country. It is difficult for tourism development, if not possible, to house more airlines. So, it will be re-constructed with a full plan.

- Transform seasonal airports into year-round operational airports.

- Airports in the hilly and mountain region will be upgraded.

- More regional air service agreements to enhance air connectivity within the region. 
- $\quad$ Fully fledged other international airports will be constructed to accommodate the amplified demand for air travel and to enhance their connectivity.

\section{Strategies no. 6 (Attract new investment)}

- International and native investors investing in rural and remote areas shall be provided with incentives.

- Encourage investment with the enactment of operational friendly laws and policies for the tourism sector.

Immediate and long term action

\section{Immediate actions}

- Nepal Tourism year-2020 shall be celebrated with the active participation of people, public and private sector.

- Tourism awareness campaign shall be arranged all over the country.

- The agricultural products will be positioned in the conventional and emerging markets. Appropriate market segmentation will be emphasized.

- Request international airlines to enhance air connectivity to operate flights to Nepal.

- Attracting investment to create tourism attractions and facilities.

- Assist the local bodies in preparing tourism management plan and in integrating it with other development plans.

- Linkages will be built up between tourism and agro-based as well as cottage industries.

- Ample focus on the security issues.

- Homestay marketing to be adopted as a key agenda by the local Chamber of Commerce.

\section{Long term actions}

- To improve cross-border agro-tourism activities like celebration of field transplanting of rice as muddy festivals based on mutual benefits, coordination will be maintained with neighboring nations.

- Development and betterment of home-stay and community -based tourism products.

- Development of Tourism Master plans, Integrated Tourism management plans of all five development regions and corresponding long term tourism strategic plan.

- Management of investment friendly policies.

- Initiate to mitigate the negative consequences of climate change.

\section{Conclusion}

Nepal has a lot to offer to experience seekers of the world who look for adrenaline thrust through agricultural tourism. However, the country is yet to realize the potential in this regard. Though there is a great potential of agro-tourism, Nepal has faced lots of ups and down. Tourists always have inner keen to involve in different agricultural activities directly or indirectly. Nepal, being an agricultural country and tourism as one of the major economic sectors, agro-tourism can be one of the new emerging tourism industries. It gives farmers considerable revenues being an alternative way of selling farmer's products and services. Hence, there is an utmost need to work for uplifting the Agro-tourism industry from governmental, nongovernmental, private and community sectors. Nepal has passed through a decade long civil war between the Maoist rioter group and the nation. Naturally, the country's economy has suffered even more because of the political turmoil. Tourism is the primary source of revenue for this small country sandwiched between the big China and India. However, the prevailing tourism does not seem to be progressing which demands other alternatives. One of the best potential alternatives could be agro-tourism development. Thus, Agro-tourism can surely do a lot of help for Nepal to improve people's social as well as economic status.

\section{ACKNOWLEDGEMENTS}

I acknowledge Mr. Bhishma Raj Dahal from Agriculture and Forestry University for his kind support and suggestion during manuscript preparation.

Open Access: This is an open access article distributed under the terms of the Creative Commons Attribution 4.0 License, which permits unrestricted use, distribution, and reproduction in any medium, provided the original author(s) if the sources are credited.

\section{REFERENCES}

Barbieri, C. and Mshenga, P. M. (2008). The role of the firm and owner characteristics on the performance of agritourism farms. Sociologia Ruralis (48): 166-183, https://doi.org/10.1111/j.1467-9523.2008.00450.x

MA, H. P. and Pandey, P. R. (2011). Socio-economic development through agrotourism: a case study of Bhaktapur, Nepal. The Journal of Agriculture and Environment, 12: 59-66.

Ammirato, S. and Felicetti, A.M. (2014). The agritourism as a means of sustainable development for rural communities: a research from the field. International Journal of Interdisciplinary Environmental Studies, 17-29, https://doi.org/10.18848/2329-1621/CGP/v08i01/53305

Andereck, K.L., Valentine, K.M., Knopf, R.C. and Vogt, C.A. (2005). Residents' perceptions of community tourism impacts. Annals of Tourism Research, 32: 1056-1076.

Andereck, K. and Vogt, C. (2000). The relationship between residents' attitudes toward tourism and tourism development options. Journal of Travel Research, 39: 27-36, https://doi.org/10.1177/004728750003900104

Ap, J. and Crompton, J.L. (1993). Residents' strategies for responding to tourism impacts. Journals of Travel Research, 33(1): 47-50.

Bhusal, K., Pokhrel, S. and Bandari , S. (2018). Promotional strategies and policies for agro-ecotourism development in different parts of Chitwan. International Journal of Graduate Research And Review, 4(4): 123-126.

Bowen, D. and Clarke, J. (2002). Reflections on tourist satisfaction research: past, present and future. Journal of Vacation Marketing, 8(4): 297-308, https://doi.org/10.1177/135676670200800401

Brunt, P. and Courtney, P. (1999). Host perceptions of sociocultural impacts. Annals of Tourism Research, 26(2): 493-515.

Dangol, R, D. and Ranabhat, B. (2007). Developing agro-ecotourism in Nepal. NTTR, 12-25.

Diedrich, A. and Garcia-Buades, E. (2009). Local perceptions of tourism as indicators of destination decline. Tourism Management, 30(4): 512-521, https://doi.org/10.1016/j.tourman.2008.10.009 
Fleischer, A. and Pizam, A. (1997). Rural tourism in israel. Tourism, 18(6): 367-37, https://doi.org/10.1016/S0261-5177(97)00034-4

Getz, D. and Carlsen, J. (2000). Characteristics and goals of family and owner-operated business in the rural tourism industry and hospitality sectors. Tourism Management, 21(6): 547-560, http://dx.doi.org/10.1016/S0261-5177(00)00004-2

Haugen, M.S. and Vik, J. (2008). Farmers as entrepreneurs: the case of farm-based tourism. International Journal of Entrepreneurship and Small Business, 6(3): 321-337.

Ilbery, B., Maye, D. and Knafsey, M. (2004). Forecasting supply chain developments in lagging rural regions. journal of rural studies, 20: 331-344.

Ismail, F. and Turner, L. (2008). Host and tourist perceptions on small island tourism: a case study of Perhentian and Redang islands, Malaysia. International Conference on Applied Economics, 36-44.

Kandampully, J. (2000). The impact of demand fluctuation on the quality of service: A Tourism Industry Example. Managing Service Quality, 10(1): 10-18, https://doi.org/10.1108/09604520010307012

Kayat, K. (2002). Power, social exchanges and tourism in Langkawi: rethinking resident perceptions. International Journal of Tourism Research, 4: 171-191.

Kiriakidou, O. and Gore, J. (2005). Learning by example: benchmarking organizational culture in hospitality, tourism and leisure SMEs. Benchmarking: An International Journal, 12(3): 192-206, http://dx.doi.org/10.1108/14635770510600320

Kumbhar, V. M. (2010). Agro-tourism scope and opportunities for the farmers in Maharashtra. 1-13.

Lankford, S.V. (1994). Attitudes and perceptions towards tourism and rural regional development. Journal of Travel Research, 32(4): 35-43.

Latip, N.A., Marzuki, A., Omar, M.U. and Pimid, M. (2015). Sustainable tourism's indicator in the protected area: the case of Kinabalu Park, Sabah. Australian Journal of Basic and Applied Sciences, 9(4): 95-103.

Long, P., Perdue, R. and Allen, L. (1990). Resident attitudes towards tourism impacts in Hawaii. Annals of Tourism Research, 13(2): 193-214.

Maharjan, S.K. and Dangol, D.R. (2018). Agritourism education and research in Nepal. Agricultural Research \& Technology: Open Access Journal, 14(5): 001-005, http://dx.doi.org/10.19080/ARTOAJ.2018.14.555932

Mascarenhas, M. (2001). Framing system research.Flexible diversification of a small family farm in Southeast Michigan. Agriculture and Human Values, 18(4): 391-101, http://doi.org/10.1023/A:1015233512117

Maude, A. J. and van Rest, D. J. (1985). The social and economic effects of farm tourism in the United Kingdom. Agricultural Administration, 20: 85-98.

$\mathrm{McCool}, \mathrm{S}$. and Martin, S. (1994). Community attachment and attitudes toward tourism development. Journal of Travel Research, 32(3): 29-34, http://doi.org/10.1177/004728759403200305

McGehee, N.G. and Kyungmi, K. (2004). Motivation for agri-tourism entrepreneurship. Journal of Travel Research: 161-170, https://doi.org/10.1177\%2F0047287504268245

Murphy, P. E. (1985). Tourism: a community approach. London: Routledge: 12-17.

Nepal Tourism Board. (2019, October). Retrieved from Nepal Tourism Board: https://www.welcomenepal.com/

Ogidi and Odiba (2014). Benchmarking as a tool of TQM in the delivery of quality services/products. SCSR Journal of Business and Entrepreneurship, 1(3): 52-63.

Ogorelc, A. (2009). Residents' perceptions of tourism impacts and sustainable tourism development. International Journal of Sustainable Economy, 1(4): 373387, http://dx.doi.org/10.1504/IJSE.2009.024763

Oppermann, M. (1995). Holidays on the farm: A case study of
German hosts and guests. Journal of Travel Research: 63-67, https://doi.org/10.1177\%2F004728759503400108

Pandey, H. and Pandey, P.R. (2011). Socio-economic development through agrotourism: a case study of Bhaktapur, Nepal. The Journal of Agriculture and Environment, 12: 59-66.

Park , D. and Yoon , Y. (2011). Developing sustainable rural tourism evaluation indicators. International Journal of Tourism Research, 13: 401-415, http://dx.doi.org/10.1002/jtr.804

Paudel, M.N. (2016). Prospects and limitations of agriculture industrialization in Nepal. Agronomy Journal of Nepal, 4: 38-63.

Putzel, S. (1984). Farm holidays: Combining agriculture and recreation. Agrologist (Fall): 20-21.

Rickard, R. C. (1983). The role of farm tourism in the less favoured areas of England and Wales. New York: Exeter: University of Exeter Agricultural Economics unit.

Ryan, C. and Cessford, G. (2003). Developing a visitor satisfaction monitoring methodology: quality gaps, crowding and some results. Current Issues in Tourism, 6(6): 457-507, http://doi.org/10.1080/13683500308667966

Sansar, N. (2019, january 25). Nepali sansar. Retrieved from Nepali sansar: https:// www.nepalisansar.com/tourism/nepal-tourist-arrivals-2019-jan-reports-25 -y-o-y-rise/

Sharpley, R. and Vass, A. (2006). Tourism, farming and diversification: an attitudinal study. Tourism Management: 1040-1052, https://doi.org/10.1016/j.tourman.2005.10.025

Singh, P. and Mishra, M.K. (2016). Identifying the potential of agri-tourism in India: overriding challenges and recommend strategies. International Journal Of Core Engineering \& Management (IJCEM), 3(3): 7-14

Sonnino, R. (2004). “For a 'piece of bread'? interpreting sustainable development through agritourism in Southern Tuscany. Sociologia Ruralis, 44(3): 285-300, https://doi.org/10.1111/j.1467-9523.2004.00276.x

Tosun, C. (2002). Host perceptions of impacts: a comparative tourism study. Annals of Tourism Research, 29: 231-253, https://doi.org/10.1016/S0160-7383(01)00039-1

Upadhyaya, R. (2006). Agro-tourism outlook. Nepal Travel Trade Reporter, 20(26): 209.

Vargas-Sánchez, A., Plaza-Mejia, M.D.L.Á. and Porras-Bueno, N. (2009). Understanding residents' attitudes toward the development of industrial tourism in a former mining community. Journal of Travel Research, 47(3), 373-387, Journal of Travel Research, 47(3): 373-387, https://doi.org/10.1177\%2F0047287508322783

Veeck, G., Che, D. and Veeck, A. (2006). America? s changing farmscape: a study of agricultural tourism in Michigan. Professional Geographer, 58(3): 63-79, https://doi.org/10.1111/j.1467-9272.2006.00565.x

Waithe, R. (2006). Caribbean agrotourism development initiatives and opportunities. Inter-American Institute for Cooperation on Agriculture (IICA). Barbados: 36-47.

Weaver, D. B. and Fennell, D. A. (1997). The vacation farm sector in Saskatchewan: a profile of operations. Tourism Management, 18(6): 357-365.

Weaver, D., Glenn, C. and Rounds, R. (1996). Private ecotourism operations in Manitoba, Canada. Journal of Sustainable Tourism, 4(3): 135-146.

Yuksel, A. and Yuksel, F. (2001a). Measurement and management issues in customer satisfaction research: Review, critique and research agenda: Part one. Journal of Travel and Tourism Marketing, 10(4): 47-80, https://doi.org/10.1300/J073v10n04_03

Yuksel, A. and Yuksel, F. (2001b). Measurement and management issues in customer satisfaction research: Review, critique and research agenda: Part two. Journal of Travel and Tourism Marketing, 10(4): 81-111, http://dx.doi.org/10.1300/J073v10n04_04 